\title{
Nutrient input alleviates negative effects of early and subsequent flooding on growth of Polygonum hydropiper with the aid of adventitious roots
}

\author{
Yu-Han Chen \\ Beijing Forestry University \\ Guan-Wen Wei \\ Beijing Forestry University \\ Yuan Cui \\ Beijing Forestry University \\ Fang-Li Luo ( $\nabla$ ecoluofangli@163.com ) \\ Beijing Forestry University \\ Bi-Cheng Dong \\ Beijing Forestry University
}

\section{Research Article}

Keywords: early flooding, eutrophication, maternal effect, silver spoon effect, submergence, Three Gorges Reservoir Region.

Posted Date: February 25th, 2022

DOl: https://doi.org/10.21203/rs.3.rs-1380480/v1

License: (c) (1) This work is licensed under a Creative Commons Attribution 4.0 International License. Read Full License 


\section{Abstract}

\section{Background and aims}

Riparian plants are commonly exposed to flooding, which is often accompanied by eutrophication. Flooding and eutrophication at an early developmental stage of riparian species may provide signals that induce plant responses and affect their performance in subsequent severe stress. However, whether early flooding (either with or without eutrophication) acts as a positive or a stress signal on plant seedlings as well as on plants at later developmental stages remains unclear.

\section{Methods}

Polygonum hydropiper plants germinated from seeds collected both at low and high elevations in the Three Gorges Reservoir Region were subjected to shallower and shorter early flooding or eutrophic flooding treatments, and subsequently subjected to deeper and longer flooding treatments.

\section{Results}

Early flooding and eutrophic flooding significantly induced generation of adventitious roots, suggesting morphological adaptation to flooding. At the end of subsequent flooding, stem length, functional leaf length and width, and biomass of plants formerly subjected to early control treatment were significantly higher than early flooding treatment, but had no significant differences compared with early eutrophic treatment, indicating that negative lag-effects of early flooding can be alleviated by nutrient input. Similarly, subsequent eutrophic flooding also enhanced plant growth compared with subsequent flooding, resulting in significantly higher values of leaf traits and adventitious root number. Plants that originated from low elevation had higher functional leaf length and stem biomass compared with plants from high elevation.

\section{Conclusions}

Nutrient input can alleviate negative effects of early and subsequent flooding on $P$. hydropipergrowth with the aid of adventitious roots.

\section{Introduction}

Flooding is one of the detrimental stresses riparian plants often encounter (Ayi et al. 2019; Ryser et al. 2011). Hypoxia and low light intensity caused by partial or complete submergence limit photosynthesis and respiration in plants, which leads to growth retardation and ultimately, plant death (Hartman et al. 2021; Kaspary et al. 2020; Kolton et al. 2020; Striker et al. 2012; Striker et al. 2014). It has been shown that simulating abiotic stress, for example by flooding at an early period, can act as a signal and induce positive plant responses to subsequent severe stresses (Li et al. 2020a; Yin et al. 2014). Once plants were subjected to flooding, both direct and indirect oxygen sensing mechanisms can quickly respond to the domestication response which can improve the floodtolerance of plants (Bailey-Serres et al. 2012; Herzog et al. 2016; Striker and Colmer 2017; Striker et al. 2019; Yang 2014). For example, Arabidopsis thaliana can accumulate Ethylene Insensitive 3 (a necessary transcription factor for regulating the ethylene reaction) within $1 \mathrm{~h}$ after the root tip has been submerged which can be used to predict an upcoming hypoxic environment and improve the hypoxia tolerance of plants (Hartman et al. 2019). In plants, these stimulation effects of flooding are often reflected by the formation of adventitious roots within several days 
or even hours after flooding (Iturralde Elortegui et al. 2020; Joshi and Ginzberg 2021). The initial stage of flooding also increases the abundances of most proteins in soybean within the first $6 \mathrm{~h}$ and induces complex response processes such as changes in the energy metabolism (Yin et al. 2014). However, negative impacts of early flooding on growth and metabolism of plant seedlings have also been shown (Lim et al. 2015; Yeap et al. 2019; Zhang et al. 2015). Whether early flooding acts as a positive induction or stress on plant seedlings and on plants at their later developmental stage remains unclear.

The Three Gorges Reservoir (TGR) in China is one of the largest reservoirs in the world (Yang et al. 2012). The water level of the TGR fluctuates repeatedly over the year from an elevation of $145 \mathrm{~m}$ in summer to $175 \mathrm{~m}$ in winter, forming a hydro-fluctuation belt (HFB) with an area of approximately $349 \mathrm{~km}^{2}$ (Lin et al. 2020). This causes plants that are naturally distributed at low and high elevations of the HFB to experience different flooding conditions and nutrient levels (Liu et al. 2019; Zhang et al. 2013). Generally, plants distributed at high elevations experience flooding at a lower frequency and for a shorter duration, while plants distributed at low elevation experience flooding at a higher frequency and for a longer duration (Chen et al. 2019; Schreiber et al. 2011). Low and high elevation plants show different responses to flooding especially regarding their leaf traits (Chen et al. 2009; Wei et al. 2020). Because the water level of the TGR rises gradually, stimulation of early flooding may induce growth and metabolic responses of certain riparian species, but these responses may differ between low and high elevation plants. Moreover, in low and high elevation plants the formation of "plastic memory" may be induced after stimulation by different levels of flooding stress for an extended period. This may be transmitted to offspring through seeds produced by sexual reproduction, thus affecting the growth performance of offspring plants such as germination, biomass accumulation, and flowering. Consequently, offspring may adjust phenotypic strategies as an adaptation to a maternally similar environment (Alvarez et al. 2021; Jiang et al. 2021; Latzel et al. 2010; Sánchez et al. 2021).

Eutrophication is very common in wetland ecosystems, including certain basins in the TGR region (Huang et al. 2020; Tercero et al. 2015; Tian et al. 2017; Wang et al. 2020). After the first impoundment of the TGR region in 2003, eutrophication and algal blooms often occur in major tributaries (Li et al. 2020b). The effect of nutrient input on plant fitness at the early stage of plant development is significant (Huber et al. 2012). Plant individuals that experience nourishing nutritional resources at the early stage of development often have higher phenotypic plasticity and lasting adaptability than plants that experience adverse conditions, i.e., see the silver-spoon effect (Hopwood et al. 2014). Therefore, eutrophication at an early developmental stage may alleviate flooding pressure on riparian plants (Qiu et al. 2020). In addition, if the environment parental plants experienced or the environment the offspring plants experienced early in their development can predict the environment adult plants will likely be exposed to. Thus, offspring plants would have higher fitness in the predicted environment at a later developmental stage (Auge et al. 2017). However, if phenotypes can respond to the parental environment and their own current environment, intragenerational plasticity is considered to evolve more easily than parental effects. The reason is that the offspring environment is more useful for predicting the future selective offspring environment than the parental environment (Alvarez et al. 2021).

The riparian plant Polygonum hydropiper is naturally distributed at both low and high elevations in the HFB in the TGR. This species has high phenotypic plasticity in response to flooding, and especially the response of leaves differs significantly between low and high elevation plants (Wei et al. 2020; Wei et al. 2021). Flooding significantly reduces its growth, but induces adventitious root formation within hours after flooding (Wei et al. 2021). Therefore, the formation of adventitious roots can be considered as one of the most important traits for plants sensing 
flooding. In this study, plants of $P$. hydropiper germinated from seeds collected from both low and high elevations were selected to address the following questions: (1) Does early flooding/eutrophic flooding affect growth of plant seedlings? (2) Does early flooding/eutrophic flooding act as positive induction or stress on plant growth at later developmental stages? (3) Are plants from low and high elevations responding differently to early and subsequent flooding?

\section{Material And Methods}

\section{Study material}

P. hydropiper L. (Polygonaceae) is an annual herb, which is a common and dominant species in different types of wetlands, such as rivers and lakes (Chen et al. 2019). It has branched stems, enlarged nodes, and lanceolate leaves. This species bears axillary spikelike racemes, blooms from May to September, and generates seeds from June to October (Wei et al. 2020).

\section{Experimental Design}

Seedlings were propagated from seeds collected from three pairs of low elevation (150-155 m above sea level (a.s.I.)) and high elevation (165-175 m a.s.I.) populations in the HFB of the TGR in September 2016. The low and high populations are located in Beibei District (E106²6'58.3", N2940'59.9"; E106 26'53.9", N2941'01.7"), Fuling

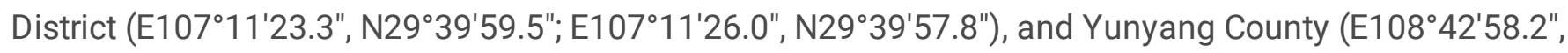
$\left.\mathrm{N} 31^{\circ} 00^{\prime} 04.8^{\prime \prime} ; \mathrm{E} 108^{\circ} 42^{\prime} 59.2^{\prime \prime}, \mathrm{N} 31^{\circ} 00^{\prime} 03.6^{\prime \prime}\right)$ in Chongqing City, China.

In June 2019, enough seeds for each population were germinated on seedling trays at the Beijing Sheng Fang greenhouse. After germination, they were transplanted into plastic pots $(11 \mathrm{~cm}$ upper diameter, $8 \mathrm{~cm}$ bottom diameter, and $9.6 \mathrm{~cm}$ height) until most of them had grown to a height of $15 \mathrm{~cm}$. For each population, 195 seedlings with uniform size were selected for the experiment. The substrate in pots was a quartz sand and vermiculite mixture ( $\mathrm{v}: \mathrm{v}, 1: 3)$, containing nutrients of $1.52 \pm 0.05 \mathrm{mg}$ total $\mathrm{N} \mathrm{g}^{-1}$ and $1.46 \pm 0.07 \mathrm{mg} \mathrm{total} \mathrm{P} \mathrm{g}^{-1}$. In August 2019, early treatments were conducted, including 3 early flooding treatments $\times 2$ elevations (low and high) $\times 65$ replicates $\times 3$ districts (Fig. 1). The three early flooding treatments included early control (no flooding), early flooding (with a floodwater depth of $1 \mathrm{~cm}$ above the soil surface), and early eutrophic flooding (with an eutrophic floodwater depth of $1 \mathrm{~cm}$ above the soil surface). The concentrations of $\mathrm{N}$ and $\mathrm{P}$ were 2 and $0.15 \mathrm{mg} \mathrm{L}^{-1}$, respectively, which were set in reference to the eutrophication level of water in the TGR (Huang et al. 2014; Tang et al. 2015; Xiang et al. 2021). Three days later, most flooded plants (more than 95\%) had generated adventitious roots. The morphologic traits of all plants were measured, including stem length, functional leaf length and width, total leaf number, and adventitious root number. A total of 90 plants were harvested ( 3 early flooding treatments $\times$ 2 elevations $\times 5$ replicates $\times 3$ districts). Plants were separated into leaves, stems, and roots (both belowground roots and adventitious roots), dried, and the biomass was measured. The remaining plants were subjected to subsequent flooding treatments: 3 early flooding treatments $\times 2$ elevations $\times 20$ replicates $\times 3$ subsequent flooding treatments $\times 3$ districts. The three subsequent flooding treatments included: control (no flooding), flooding (where the floodwater depth was $7 \mathrm{~cm}$ above the soil surface, and nearly at half of the plant height), and eutrophic flooding (where the eutrophic floodwater depth was $7 \mathrm{~cm}$ above the soil surface). The concentrations of $\mathrm{N}$ and $\mathrm{P}$ 
were the same as in early eutrophic flooding treatment. The experiment lasted for three months. The air temperature in the greenhouse ranged from $28-35^{\circ} \mathrm{C}$ and the relative air humidity ranged from $40-60 \%$ at noon.

\section{Growth Measurements}

The time of harvesting of these 90 plants after 3 days of induction treatments was defined as day 0 of subsequent treatments. During subsequent treatments, adventitious root number was measured on days $1,3,5,7$, $10,13,16$, and 20 . A total of 270 plants ( 3 early flooding treatments $\times 2$ elevations $\times 5$ replicates $\times 3$ subsequent flooding treatments $\times 3$ districts) were harvested every five days for four times and dried in an oven at $70^{\circ} \mathrm{C}$ for at least $72 \mathrm{~h}$ to measure root biomass on days 5,10 , and 15 , and leaf, stem, root, and adventitious root biomass on day 20. And then, the root to shoot ratio was calculated.

\section{Data Analyses}

Before analyses, data were assessed for normality and homogeneity of variance. For early treatments, two-way ANOVA was used to test for effects of early treatments (fixed effect) and elevation (fixed effect) on stem length, functional leaf length and width, total leaf number, leaf biomass, stem biomass, root biomass, total biomass, root to shoot ratio, and adventitious root number. For subsequent treatments, three-way ANOVA was used to test for effects of early treatments (fixed effect), subsequent treatments (fixed effect), and elevation (fixed effect) on stem length, functional leaf length and width, total leaf number, leaf biomass, stem biomass, root biomass, total biomass, root to shoot ratio, adventitious root number, and adventitious root biomass. Plant height on day 1 of the subsequent treatments was set as covariate for all growth variables. Analyses were conducted using $\mathrm{R}$, version 4.1.1 (R Core Team 2021).

\section{Results}

Early treatments had significant effects on adventitious root number but did not significantly affect other growth variables (Table 1). The generation of adventitious roots in both early flooding and eutrophic flooding treatments started on day 1 and retained a high generation rate until day 7 , but no adventitious roots were found in early control treatment (Supplementary Fig. 1a-c). Early flooding and eutrophic flooding treatments did not show significant differences in adventitious root number (Fig. 2). The elevation and interaction of elevation and early treatments had no significant effect on any of growth variables (Table 1). 
Table 1

ANOVA results for effects of early treatments (ET: early control, early flooding, and early eutrophic flooding) and elevations (E: low and high) on stem length, functional leaf length and width, total leaf number, leaf biomass, stem biomass, root biomass, total biomass, root to shoot ratio, and adventitious root number in Polygonum hydropiper at the end of early treatments.

\begin{tabular}{|c|c|c|c|c|c|c|}
\hline \multirow[t]{3}{*}{ Trait } & \multirow{2}{*}{\multicolumn{2}{|c|}{$\begin{array}{l}\text { Early treatments } \\
\text { (ET) }\end{array}$}} & \multirow{2}{*}{\multicolumn{2}{|c|}{$\begin{array}{l}\text { Elevation } \\
\text { (E) }\end{array}$}} & \multirow{2}{*}{\multicolumn{2}{|c|}{$\mathrm{ET} \times \mathrm{E}$}} \\
\hline & & & & & & \\
\hline & $F_{2,84}$ & $P$ & $F_{1,84}$ & $P$ & $F_{2,84}$ & $P$ \\
\hline Stem length & 0.06 & 0.944 & 0.01 & 0.909 & 0.42 & 0.660 \\
\hline Functional leaf length & 0.20 & 0.818 & 1.10 & 0.297 & 0.48 & 0.623 \\
\hline Functional leaf width & 0.91 & 0.409 & 0.35 & 0.556 & 2.59 & 0.081 \\
\hline Total leaf number & 0.09 & 0.919 & 1.33 & 0.252 & 1.95 & 0.149 \\
\hline Leaf biomass & 0.04 & 0.957 & 0.45 & 0.504 & 2.12 & 0.126 \\
\hline Stem biomass & 0.12 & 0.886 & 3.30 & 0.073 & 1.61 & 0.206 \\
\hline Root biomass & 1.30 & 0.279 & 1.15 & 0.287 & 1.76 & 0.179 \\
\hline Total biomass & 0.07 & 0.929 & 1.50 & 0.223 & 1.98 & 0.145 \\
\hline Root to shoot ratio & 1.35 & 0.263 & 1.71 & 0.195 & 0.23 & 0.798 \\
\hline Adventitious root number & 76.95 & $<0.001$ & 0.85 & 0.361 & 0.24 & 0.790 \\
\hline
\end{tabular}

Early treatments had significant effects on all growth variables except for root to shoot ratio and adventitious root biomass of plants on day 20 (Table 2). The stem length, functional leaf length and width, leaf biomass, stem biomass, root biomass, and total biomass of plants formerly subjected to early control treatment showed no significant differences compared with early eutrophic treatment, but was significantly higher than early flooding treatment (Fig. 3). 
Table 2

ANOVA results for effects of ET, subsequent treatments (ST: control, flooding, and eutrophic flooding), and E on stem length, functional leaf length and width, total leaf number, leaf biomass, stem biomass, root biomass, total biomass, root to shoot ratio, adventitious root number, and adventitious root biomass in $P$. hydropiperat the end of subsequent treatments.

\begin{tabular}{|c|c|c|c|c|c|c|c|}
\hline \multirow[t]{2}{*}{ Trait } & $\begin{array}{l}\text { Early } \\
\text { treatments } \\
\text { (ET) }\end{array}$ & $\begin{array}{l}\text { Subsequent } \\
\text { treatments } \\
\text { (ST) }\end{array}$ & $\begin{array}{l}\text { Elevation } \\
\text { (E) }\end{array}$ & ST $^{\text {ST }}$ & $\mathrm{ET}_{\mathrm{E}}^{\mathrm{T}} \mathrm{x}$ & $\begin{array}{l}\text { ST } x \\
\mathrm{E}\end{array}$ & $\begin{array}{l}\text { ET } x \\
\text { ST } x \\
\text { E }\end{array}$ \\
\hline & $F_{2,251}$ & $F_{2,251}$ & $F_{1,251}$ & $F_{4,251}$ & $F_{2,251}$ & $F_{2,251}$ & $F_{4,251}$ \\
\hline $\begin{array}{l}\text { Stem } \\
\text { length }\end{array}$ & $24.38^{\star \star \star k}$ & 0.65 & 0.16 & 0.41 & 0.29 & 0.17 & 1.43 \\
\hline FLL & $16.22^{* k *}$ & 1.26 & $22.69^{* k *}$ & 1.95 & 0.38 & 0.00 & 0.10 \\
\hline FLW & $8.93^{* \star *}$ & $4.35^{*}$ & $4.86^{*}$ & 0.32 & 1.21 & 0.12 & 1.33 \\
\hline $\begin{array}{l}\text { Total } \\
\text { leaf } \\
\text { number }\end{array}$ & $3.36^{*}$ & $30.77^{* \star \hbar k}$ & 0.55 & 1.02 & 0.75 & 0.02 & 1.34 \\
\hline $\begin{array}{l}\text { Leaf } \\
\text { biomass }\end{array}$ & $13.58^{* \star k *}$ & $6.78^{* *}$ & 2.72 & 1.86 & 2.31 & 0.08 & 1.13 \\
\hline $\begin{array}{l}\text { Stem } \\
\text { biomass }\end{array}$ & $29.02^{* * k}$ & 2.33 & $13.19^{\star \star k *}$ & 1.22 & 1.62 & 0.07 & 0.60 \\
\hline $\begin{array}{l}\text { Root } \\
\text { biomass }\end{array}$ & $20.63^{* * k}$ & $147.87^{\star \star \star}$ & 1.56 & 1.66 & 1.30 & 0.43 & 0.92 \\
\hline $\begin{array}{l}\text { Total } \\
\text { biomass }\end{array}$ & $23.22^{* \star *}$ & $3.49^{*}$ & $7.29^{* \star}$ & 1.75 & 2.12 & 0.05 & 0.84 \\
\hline $\begin{array}{l}\text { Root to } \\
\text { shoot } \\
\text { ratio }\end{array}$ & 0.55 & $4.95^{\star *}$ & 0.94 & 1.35 & 1.80 & 0.24 & 0.29 \\
\hline ARN & $4.55^{*}$ & $501.68^{\star \star \star}$ & 1.96 & 1.24 & 0.53 & 0.31 & 0.34 \\
\hline ARB & 1.69 & $101.50^{\star \star \star}$ & 0.24 & 1.10 & 0.62 & 0.29 & 0.40 \\
\hline \multicolumn{8}{|c|}{ 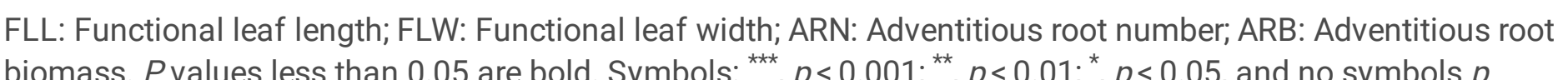 } \\
\hline
\end{tabular}

Subsequent treatments had significant effects on all growth variables except for stem length, functional leaf length, and stem biomass of plants on day 20 (Table 2). The leaf width, leaf number, and leaf biomass of plants in the subsequent control and eutrophic flooding treatments were significantly higher than in the subsequent flooding treatment (Fig. $4 \mathrm{~b}-\mathrm{d}$ ). The leaf length, stem biomass, total biomass, and root to shoot ratio of plants in the subsequent control treatment were not significantly different compared with subsequent eutrophic treatment, but these variables were significantly higher than in subsequent flooding treatment (Fig. 4a, e, g, h). Both subsequent flooding and eutrophic flooding treatments stimulated the generation of adventitious roots, with a higher number in subsequent eutrophic flooding; however, these two treatments significantly suppressed root growth (Fig. 4f, i, j; Supplementary Fig. 1d-f). Elevation had significant effects on functional leaf length and width, 
stem biomass, and total biomass (Table 2). Plants that originated from the low elevation had significantly higher functional leaf length and stem biomass compared with plants from the high elevation (Fig. 5).

\section{Discussion}

Studies have shown that early abiotic stresses stimulate positive responses in plants for coping with subsequent severer stress (Avramova 2019; Harb et al. 2010; Hatzig et al. 2018; Li et al. 2020a; Li et al. 2022; Mantoan et al. 2020; Nosalewicz et al. 2018; Zamorano et al. 2021). Many studies have also shown no significant effects or even negative effects of early stresses (Ahmad et al. 2011; Araki et al. 2012; Barickman et al. 2019; Pavlović et al. 2019; Ploschuk et al. 2020; Zhou et al. 2020). These results showed that short early flooding induced morphological adaptation to flooding, manifesting as the generation of adventitious roots. However, it did not improve growth responses to subsequent flooding, and a significant decrease in growth variables was observed. In comparison, plants in early eutrophic flooding treatment did not show a significant decrease in growth variables compared with plants in the control treatment. These results suggest negative lag-effects of early flooding, further indicating that nutrient input can alleviate such effects.

Flooding has detrimental effects for the growth of many riparian plants; however, in conditions of nutrient enrichment, plants can absorb and utilize nutrients to offset the negative effects of flooding (Qiu et al. 2020). Plant individuals growing in benign habitats at the early developmental stage often have higher fitness at later developmental stages (Engqvist and Reinhold 2016). Especially, when the conditions at later developmental stages are comparatively hostile, such an effect becomes more important (Portela et al. 2020). Benign resource conditions such as light and nutrient availability at the early stage also determine the subsequent phenotypic responses of Rumex palustris and may produce different adaptive strategies in response to spatially or temporally heterogeneous conditions (Chen et al. 2011; Huber et al. 2012). The reasons why early eutrophic treatment did not significantly increase the growth of $P$. hydropiper at the end of the subsequent treatments may be that positive effects of nutrient input on plant growth are not sufficiently large to offset the negative effects of flooding, showing an overall negative effect (Nguyen et al. 2018b). Moreover, most studies on the silver spoon effect have found a time-lag effect (Van Allen and Rudolf 2015). If experiments last long enough, the effect of early eutrophic flooding on plant growth may become more apparent.

Subsequent eutrophic flooding also improved plant growth compared with subsequent flooding, yielding significantly higher growth of leaves and adventitious roots (Fig. 4), indicating a higher adaptation induced by subsequent eutrophic flooding (Joshi and Ginzberg 2021). The increase of plant growth in the eutrophic flooding treatment may be based on the form of added nitrogen. In this study, nitrate was added which reportedly plays a beneficial role in maintaining photosynthetic metabolism during short-term flooding (Borella et al. 2019; Da-Silva et al. 2021; Nguyen et al. 2018a; Posso et al. 2020). Upon flooding, because of the inhibited growth of belowground roots, plants of $P$. hydropipermay prioritize the allocation of resources obtained from eutrophic water to grow leaves and adventitious roots.

The compensation for biomass loss of offspring plants under stress is not only driven by the environment offspring plants experience, but it can also be driven by their parents (Latzel et al. 2010; Quan et al. 2021). The environmental stress experienced by parental plants can form a kind of "memory", which affects seeds and the growth performance of offspring plants (Bossdorf et al. 2009; Li et al. 2021; Waterman and Sultan 2021). Compared with plants from high elevation, plants from low elevation had significantly higher stem biomass and functional leaf length. For the maternal generation, $P$. hydropiper populations that originated from the high 
elevation are often flooded shallower and less frequently compared to populations from the low elevation, which may weaken their ability to respond to sudden environmental stress. Offspring plants that originated from the low elevation may have higher adaptability in response to this "predictable" periodic stress (Herman et al. 2012; van Dooren et al. 2020). Our former studies also reported such different strategies of $P$. hydropiperpopulations in low and high elevations (Chen et al. 2020; Wei et al. 2020; Wei et al. 2021). The differences in flooding regimes of low and high elevations may also induce epigenetic variation in the maternal generation, which can be transmitted to the offspring, leading to phenotypic variations (Benson et al. 2021; González et al. 2016; González et al. 2018; Sánchez et al. 2021).

The responses in roots appeared more quickly than those in shoots during early flooding treatments (Joshi and Ginzberg 2021; Panozzo et al. 2019). Early flooding and eutrophic flooding treatments quickly generated adventitious roots but did not affect other growth variables (Supplementary Fig. 1). Fast generation of adventitious roots may facilitate oxygen diffusion and improve aeration of flooded organs (Ayi et al. 2016; Park et al. 2020), which has been proved to be caused by ethylene accumulating because of limited gas diffusion in floodwater (Herzog et al. 2016; Joshi and Ginzberg 2021; Voesenek and Bailey-Serres 2015). In response to flooding, plants often prioritize activities related to survive such as aeration and nutrient absorption, with faster responses in roots than in shoots (Kaspary et al. 2020; Striker et al. 2014; Vidoz et al. 2016).

\section{Conclusions}

The results of this study clearly showed that early flooding and eutrophic flooding treatments quickly induced the generation of adventitious roots in $P$. hydropiper. Early flooding exerted a negative lag-effect on plant growth at the end of subsequent flooding, which could be alleviated by nutrient input. Moreover, nutrient input also alleviated negative effects of subsequent flooding. Therefore, nutrient input can alleviate negative effects of early and subsequent flooding because of the quick induction of adventitious root growth. However, if plants do not generate adventitious roots upon flooding, the effect of nutrient input may not be apparent, which will be further studied in the future. It is possible that the growth of riparian flood-tolerant species could be promoted under eutrophic conditions in the reservoir area.

\section{Declarations}

\section{Acknowledgments}

We sincerely thank Sun Xin-Sheng for his assistance in conducting greenhouse experiments, plant harvesting, and index determination.

\section{Author contributions}

Y-HC, G-WW, F-LL, and B-CD conceived and designed the study. G-WW participated in the field work and provided study materials. Y-HC carried out greenhouse experiments, analyzed the data, and wrote the manuscript. YC and F-LL participated in the structuring and editing of the manuscript. F-LL and B-CD wrote and revised the manuscript. All authors contributed to this manuscript and approved the submitted version. 


\section{Funding}

This work was supported by the Fundamental Research Funds for the Central Universities (grant number 2021ZY90), the National Natural Science Foundation of China (grant numbers 32071525).

\section{Data availability}

The datasets generated for this study are available on request from the corresponding author.

\section{Conflict of interest}

The authors have no conflicts of interest or competing interests to declare.

\section{References}

1. Ahmad MSA, Ashraf M, Tabassam Q, Hussain M, Firdous H (2011) Lead (Pb)-induced regulation of growth, photosynthesis, and mineral nutrition in maize (Zea mays L.) plants at early growth stages. Biol Trace Elem Res 144:1229-1239. https://doi.org/10.1007/s12011-011-9099-5

2. Alvarez M, Bleich A, Donohue K (2021) Genetic differences in the temporal and environmental stability of transgenerational environmental effects. Evolution 75:2773-2790. https://doi.org/10.1111/evo.14367

3. Araki H, Hamada A, Hossain MA, Takahashi T (2012) Waterlogging at jointing and/or after anthesis in wheat induces early leaf senescence and impairs grain filling. Field Crop Res 137:27-36.

https://doi.org/10.1016/j.fcr.2012.09.006

4. Auge GA, Leverett LD, Edwards BR, Donohue K (2017) Adjusting phenotypes via within- and acrossgenerational plasticity. New Phytol 216:343-349. https://doi.org/10.1111/nph.14495

5. Avramova Z (2019) Defence-related priming and responses to recurring drought: two manifestations of plant transcriptional memory mediated by the ABA and JA signalling pathways. Plant Cell Environ 42:983-997. https://doi.org/10.1111/pce.13458

6. Ayi QL, Zeng B, Liu JH, Li SQ, van Bodegom PM, Cornelissen JHC (2016) Oxygen absorption by adventitious roots promotes the survival of completely submerged terrestrial plants. Ann Bot-London 118:675-683. https://doi.org/10.1093/aob/mcw051

7. Ayi QL, Zeng B, Yang K, Lin F, Zhang XP, van Bodegom PM, Cornelissen JHC (2019) Similar growth performance but contrasting biomass allocation of root-flooded terrestrial plant Alternanthera philoxeroides (Mart.) Griseb. in response to nutrient versus dissolved oxygen stress. Front Plant Sci 10:111. https://doi.org/10.3389/fpls.2019.00111

8. Bailey-Serres J, Fukao T, Gibbs DJ, Holdsworth MJ, Lee SC, Licausi F, Perata P, Voesenek LACJ, Dongen JTV (2012) Making sense of low oxygen sensing. Trends Plant Sci 17:129-138. https://doi.org/10.1016/j.tplants.2011.12.004

9. Barickman TC, Simpson CR, Sams CE (2019) Waterlogging causes early modification in the physiological performance, carotenoids, chlorophylls, proline, and soluble sugars of cucumber plants. Plants-Basel 8:160. https://doi.org/10.3390/plants8060160 
10. Benson CW, Mao Q, Huff DR (2021) Global DNA methylation predicts epigenetic reprogramming and transgenerational plasticity in Poa annua L. Crop Sci 61:3011-3022. https://doi.org/10.1002/csc2.20337

11. Borella J, Becker R, Lima MC, de Oliveira DSD, Braga EJB, de Oliveira ACB, do Amarante L (2019) Nitrogen source influences the antioxidative system of soybean plants under hypoxia and re-oxygenation. Sci Agr 76:51-62. https://doi.org/10.1590/1678-992X-2017-0195

12. Bossdorf O, Shuja Z, Banta JA (2009) Genotype and maternal environment affect belowground interactions between Arabidopsis thaliana and its competitors. Oikos 118:1541-1551. https://doi.org/10.1111/j.16000706.2009.17559.x

13. Chen X, Huber H, de Kroon H, Peeters AJM, Poorter H, Voesenek LACJ, Visser EJW (2009) Intraspecific variation in the magnitude and pattern of flooding-induced shoot elongation in Rumex palustris. Ann BotLondon 104:1057-1067. https://doi.org/10.1093/aob/mcp198

14. Chen X, Visser EJW, de Kroon H, Pierik R, Voesenek LACJ, Huber H (2011) Fitness consequences of natural variation in flooding-induced shoot elongation in Rumex palustris. New Phytol 190:409-420. https://doi.org/10.1111/j.1469-8137.2010.03639.x

15. Chen XS, Li YF, Cai YH, Xie YH, Deng ZM, Li F, Hou ZY (2019) Differential strategies to tolerate flooding in Polygonum hydropiper plants originating from low- and high-elevation habitats. Front Plant Sci 9:1970. https://doi.org/10.3389/fpls.2018.01970

16. Chen YH, Luo YF, Sun XS, Wei GW, Huang WJ, Luo FL, Yu FH (2020) Effects of waterlogging and increased soil nutrients on growth and reproduction of Polygonum hydropiper in the hydro-fluctuation belt of the Three Gorges Reservoir Region. Chin J Plant Ecol 44:1184-1194. https://doi.org/10.17521/cjpe.2020.0159

17. Da-Silva CJ, Shimoia EP, Posso DA, Cardoso AA, Batz TA, Oliveira ACB, do Amarante L (2021) Nitrate nutrition increases foliar levels of nitric oxide and waterlogging tolerance in soybean. Acta Physiol Plant 43:116. https://doi.org/10.1007/s11738-021-03291-5

18. Engqvist L, Reinhold K (2016) Adaptive trans-generational phenotypic plasticity and the lack of an experimental control in reciprocal match/mismatch-experiments. Methods Ecol Evol 7:1482-1488. https://doi.org/10.1111/2041-210X.12618

19. González APR, Chrtek J, Dobrev PI, Dumalasová V, Fehrer J, Mráz P, Latzel V (2016) Stress-induced memory alters growth of clonal off spring of white clover (Trifolium repens). Am J Bot 103:1567-1574. https://doi.org/10.3732/ajb.1500526

20. González APR, Preite V, Verhoeven KJF, Latzel V (2018) Transgenerational effects and epigenetic memory in the clonal plant Trifolium repens. Front Plant Sci 9:1677. https://doi.org/10.3389/fpls.2018.01677

21. Harb A, Krishnan A, Ambavaram MM, Pereira A (2010) Molecular and physiological analysis of drought stress in Arabidopsis reveals early responses leading to acclimation in plant growth. Plant physiol 154:1254-1271. https://doi.org/10.1104/pp.110.161752

22. Hartman S, Liu ZG, van Veen H, Vicente J, Reinen E, Martopawiro S, Zhang HT, van Dongen N, Bosman F, Bassel GW, Visser EJW, Bailey-Serres J, Theodoulou FL, Hebelstrup KH, Gibbs DJ, Holdsworth MJ, Sasidharan R, Voesenek LACJ (2019) Ethylene-mediated nitric oxide depletion pre-adapts plants to hypoxia stress. Nat Commun 10:4020. https://doi.org/10.1038/s41467-019-12045-4

23. Hartman S, Sasidharan R, Voesenek LACJ (2021) The role of ethylene in metabolic acclimations to low oxygen. New Phytol 229:64-70. https://doi.org/10.1111/nph.16378 
24. Hatzig SV, Nuppenau J-N, Snowdon RJ, SchießI SV (2018) Drought stress has transgenerational effects on seeds and seedlings in winter oilseed rape (Brassica napus L.). BMC Plant Biol 18:297. https://doi.org/10.1186/s12870-018-1531-y

25. Herman JJ, Sultan SE, Horgan-Kobelski T, Riggs C (2012) Adaptive transgenerational plasticity in an annual plant: grandparental and parental drought stress enhance performance of seedlings in dry soil. Integr Comp Biol 52:77-88. https://doi.org/10.1093/icb/ics041

26. Herzog M, Striker GG, Colmer TD, Pedersen O (2016) Mechanisms of waterlogging tolerance in wheat - a review of root and shoot physiology. Plant Cell Environ 39:1068-1086. https://doi.org/10.1111/pce.12676

27. Hopwood PE, Moore AJ, Royle NJ (2014) Effects of resource variation during early life and adult social environment on contest outcomes in burying beetles: a context-dependent silver spoon strategy? P Roy Soc BBiol Sci 281:20133102. https://doi.org/10.1098/rspb.2013.3102

28. Huang YL, Zhang P, Liu DF, Yang ZJ, Ji DB (2014) Nutrient spatial pattern of the upstream, mainstream and tributaries of the Three Gorges Reservoir in China. Environ Monit Assess 186:6833-6847. https://doi.org/10.1007/s10661-014-3892-5

29. Huang YN, Li YP, Ji DB, Nwankwegu AS, Lai QY, Yang ZJ, Wang K, Wei J, Norgbey E (2020) Study on nutrient limitation of phytoplankton growth in Xiangxi Bay of the Three Gorges Reservoir, China. Sci Total Environ 723:138062. https://doi.org/10.1016/j.scitotenv.2020.138062

30. Huber H, Chen X, Hendriks M, Keijsers D, Voesenek LACJ, Pierik R, Poorter H, Kroon HD, Visser EJW (2012) Plasticity as a plastic response: how submergence-induced leaf elongation in Rumex palustris depends on light and nutrient availability in its early life stage. New Phytol 194:572-582. https://doi.org/10.1111/j.14698137.2012.04075.x

31. Iturralde Elortegui MdRM, Berone GD, Striker GG, Martinefsky MJ, Monterubbianesi MG, Assuero SG (2020) Anatomical, morphological and growth responses of Thinopyrum ponticum plants subjected to partial and complete submergence during early stages of development. Funct Plant Biol 47:757-768. https://doi.org/10.1071/fp19170

32. Jiang L, Wen ZB, Zhang YL, Zhao ZY, Tanveer M, Tian CY, Wang L (2021) Transgenerational effects of maternal water condition on the growth, $\mathrm{C}: \mathrm{N}$ stoichiometry and seed characteristics of the desert annual Atriplex aucheri. Plants-Basel 10:2362. https://doi.org/10.3390/plants10112362

33. Joshi M, Ginzberg I (2021) Adventitious root formation in crops-Potato as an example. Physiol Plant 172. https://doi.org/10.1111/ppl.13305

34. Kaspary TE, Roma-Burgos N, Merotto A Jr (2020) Snorkeling strategy: tolerance to flooding in rice and potential application for weed management. Genes-Basel 11:975. https://doi.org/10.3390/genes11090975

35. Kolton A, Keska K, Czernicka M (2020) Selection oftomato and cucumber accessions for waterlogging sensitivity through morpho-physiological assessment at an early vegetative stage. Agronomy-Basel 10:1490. https://doi.org/10.3390/agronomy10101490

36. Latzel V, Klimešová J, Hájek T, Gómez S, Šmilauer P (2010) Maternal effects alter progeny's response to disturbance and nutrients in two Plantago species. Oikos 119:1700-1710. https://doi.org/10.1111/j.16000706.2010.18737.x

37. Li H, Li Z, Shen ZJ, Luo MR, Liu YL, Wei MY, Wang WH, Qin YY, Gao CH, Li KK, Ding QS, Zhang S, Zhang XM, Gao GF, Zhu XY, Zheng HL (2020a) Physiological and proteomic responses of mangrove plant Avicennia 
marina seedlings to simulated periodical inundation. Plant Soil 450:231-254.

https://doi.org/10.1007/s11104-020-04474-8

38. Li XL, Hu NN, Yin JJ, Ren WB, Fry E (2021) Historic grazing enhances root-foraging plasticity rather than nitrogen absorbability in clonal offspring of Leymus chinensis. Plant Soil 466:65-79. https://doi.org/10.1007/s11104-021-05033-5

39. Li XL, Jimoh SO, Li YH, Duan JJ, Cui YW, Jin K, Wang Z, Zhang Y (2022) Stress memory and phyllosphere/soil legacy underlie tolerance and plasticity of Leymus chinensis to periodic drought risk. Agr For Meteorol 312:108717. https://doi.org/10.1016/j.agrformet.2021.108717

40. Li XT, Liu B, Wang YM, Yang YA, Liang RF, Peng FJ, Xue SD, Zhu ZX, Li KF (2020b) Hydrodynamic and environmental characteristics of a tributary bay influenced by backwater jacking and intrusions from a main reservoir. Hydrol Earth Syst Sc 24:5057-5076. https://doi.org/10.5194/hess-24-5057-2020

41. Lim CAA, Awan TH, Cruz PCS, Chauhan BS (2015) Influence of environmental factors, cultural practices, and herbicide application on seed germination and emergence ecology of Ischaemum rugosum Salisb. PLoS ONE 10:e0137256. https://doi.org/10.1371/journal.pone.0137256

42. Lin JJ, Zhou S, Liu D, Zhang S, Yu ZG, Yang XX (2020) Relative contribution of environmental and nutritional variables to net primary production of Cynodon dactylon (Linn.) Pers in the riparian zone of a Three Gorges tributary. Ecol Evol 10:7073-7081. https://doi.org/10.1002/ece3.6409

43. Liu MZ, Liu YY, Zeng B, Niu HG, Liu SP, Pan XJ, Xie JJ, Shi SH, Lin F (2019) Lowest elevation of plant growth and soil characteristics in natural drawdown areas in the Jiangjin section of the Yangtze River. Wetlands 39:381-391. https://doi.org/10.1007/s13157-018-1087-5

44. Mantoan LPB, Corrêa CV, Rainho CA, de Almeida LFR (2020) Rapid dehydration induces long-term water deficit memory in sorghum seedlings: advantages and consequences. Environ Exp Bot 180:104252. https://doi.org/10.1016/j.envexpbot.2020.104252

45. Nguyen LTT, Osanai Y, Anderson IC, Bange MP, Braunack M, Tissue DT, Singh BK (2018a) Impacts of waterlogging on soil nitrification and ammonia-oxidizing communities in farming system. Plant Soil 426:299-311. https://doi.org/10.1007/s11104-018-3584-y

46. Nguyen LTT, Osanai Y, Anderson IC, Bange MP, Tissue DT, Singh BK (2018b) Flooding and prolonged drought have differential legacy impacts on soil nitrogen cycling, microbial communities and plant productivity. Plant Soil 431:371-387. https://doi.org/10.1007/s11104-018-3774-7

47. Nosalewicz A, Siecińska J, Kondracka K, Nosalewicz M (2018) The functioning of Festuca arundinacea and Lolium perenne under drought is improved to a different extend by the previous exposure to water deficit. Environ Exp Bot 156:271-278. https://doi.org/10.1016/j.envexpbot.2018.09.016

48. Panozzo A, Dal Cortivo C, Ferrari M, Vicelli B, Varotto S, Vamerali T (2019) Morphological changes and expressions of $A O X 1 A, C Y P 81 D 8$, and putative PFP genes in a large set of commercial maize hybrids under extreme waterlogging. Front Plant Sci 10:62. https://doi.org/10.3389/fpls.2019.00062

49. Park SU, Lee CJ, Kim SE, Lim YH, Lee HU, Nam SS, Kim HS, Kwak SS (2020) Selection of flooding stress tolerant sweetpotato cultivars based on biochemical and phenotypic characterization. Plant Physiol Bioch 155:243-251. https://doi.org/10.1016/j.plaphy.2020.07.039

50. Pavlović I, Mlinarić S, Tarkowská D, Oklestkova J, Novák O, Lepeduš H, Bok VV, Brkanac SR, Strnad M, Salopek-Sondi B (2019) Early Brassica crops responses to salinity stress: a comparative analysis between Chinese cabbage, white cabbage, and kale. Front Plant Sci 10:450. https://doi.org/10.3389/fpls.2019.00450

Page 13/20 
51. Ploschuk RA, Miralles DJ, Colmer TD, Ploschuk EL, Striker GG (2020) Waterlogging of winter crops at early and late stages: impacts on leaf physiology, growth and yield. Front Plant Sci 10:1863.

https://doi.org/10.3389/fpls.2019.01806

52. Portela R, Dong BC, Yu FH, Barreiro R, Roiloa SR, Silva Matos DM (2020) Trans-generational effects in the clonal invader Alternanthera philoxeroides. J Plant Ecol 13:122-129. https://doi.org/10.1093/jpe/rtz043

53. Posso DA, Borella J, Reissig GN, do Amarante L, Bacarin MA (2020) Nitrate-mediated maintenance of photosynthetic process by modulating hypoxic metabolism of common bean plants. Acta Physiol Plant 42:117. https://doi.org/10.1007/s11738-020-03107-y

54. Qiu SY, Liu SS, Wei SJ, Cui XH, Nie M, Huang JX, He Q, Ju RT, Li B, Chu CJ (2020) Changes in multiple environmental factors additively enhance the dominance of an exotic plant with a novel trade-off pattern. $J$ Ecol 108:1989-1999. https://doi.org/10.1111/1365-2745.13386

55. Quan JX, Latzel V, Tie D, Zhang YH, Munzbergova Z, Chai YF, Liu X, Yue M (2021) Ultraviolet B radiation triggers DNA methylation change and affects foraging behavior of the clonal plant Glechoma longituba. Front Plant Sci 12:633982. https://doi.org/10.3389/fpls.2021.633982

56. R Core Team (2021) R: a language and environment for statistical computing. R Foundation for Statistical Computing, Vienna, Austria

57. Ryser P, Gill HK, Byrne CJ (2011) Constraints of root response to waterlogging in Alisma triviale. Plant Soil 343:247-260. https://doi.org/10.1007/s11104-011-0715-0

58. Sánchez AL, Pascual-Pardo D, Furci L, Roberts MR, Ton J (2021) Costs and benefits of transgenerational induced resistance in Arabidopsis. Front Plant Sci 12:644999. https://doi.org/10.3389/fpls.2021.644999

59. Schreiber CM, Zeng B, Temperton VM, Rascher U, Kazda M, Schurr U, Höltkemeier A, Kuhn AJ (2011) Dynamics of organic acid occurrence under flooding stress in the rhizosphere of three plant species from the water fluctuation zone of the Three Gorges Reservoir, P.R. China. Plant Soil 344:111-129. https://doi.org/10.1007/s11104-011-0732-z

60. Striker GG, Izaguirre RF, Manzur ME, Grimoldi AA (2012) Different strategies of Lotus japonicus, L. corniculatus and $L$. tenuis to deal with complete submergence at seedling stage. Plant Biol 14:50-55. https://doi.org/10.1111/j.1438-8677.2011.00493.x

61. Striker GG, Casas C, Manzur ME, Ploschuk RA, Casal JJ (2014) Phenomic networks reveal largely independent root and shoot adjustment in waterlogged plants of Lotus japonicus. Plant Cell Environ 37:2278-2293. https://doi.org/10.1111/pce.12268

62. Striker GG, Colmer TD (2017) Flooding tolerance of forage legumes. J Exp Bot 68:1851-1872. https://doi.org/10.1093/jxb/erw239

63. Striker GG, Kotula L, Colmer TD (2019) Tolerance to partial and complete submergence in the forage legume Melilotus siculus: an evaluation of 15 accessions for petiole hyponastic response and gas-filled spaces, leaf hydrophobicity and gas films, and root phellem. Ann Bot-London 123:169-180.

https://doi.org/10.1093/aob/mcy153

64. Tang JL, Wang T, Zhu B, Zhao P, Xiao Y, Wang R (2015) Tempo-spatial analysis of water quality in tributary bays of the Three Gorges Reservoir region (China). Environ Sci Pollut Res 22:16709-16720. https://doi.org/10.1007/s11356-015-4805-z

65. Tercero MC, Álvarez-Rogel J, Conesa HM, Ferrer MA, Calderón AA, López-Orenes A, González-Alcaraz MN (2015) Response of biogeochemical processes of the water-soil-plant system to experimental flooding-drying 
conditions in a eutrophic wetland: the role of Phragmites australis. Plant Soil 396:109-125.

https://doi.org/10.1007/s11104-015-2589-z

66. Tian ZB, Zheng BH, Wang LJ, Li LQ, Wang X, Li H, Norra S (2017) Long term (1997-2014) spatial and temporal variations in nitrogen in Dongting Lake, China. PLoS ONE 12.

https://doi.org/10.1371/journal.pone.0170993

67. Van Allen BG, Rudolf VHW (2015) Habitat-mediated carry-over effects lead to context-dependent outcomes of species interactions. J Anim Ecol 84:1646-1656. https://doi.org/10.1111/1365-2656.12408

68. van Dooren TJM, Silveira AB, Gilbault E, Jiménez-Gómez JM, Martin A, Bach L, Tisné S, Quadrana L, Loudet O, Colot V (2020) Mild drought in the vegetative stage induces phenotypic, gene expression, and DNA methylation plasticity in Arabidopsis but no transgenerational effects. J Exp Bot 71:3588-3602. https://doi.org/10.1093/jxb/eraa132

69. Vidoz ML, Mignolli F, Aispuru HT, Mroginski LA (2016) Rapid formation of adventitious roots and partial ethylene sensitivity result in faster adaptation to flooding in the aerial roots (aer) mutant of tomato. Sci Hortic 201:130-139. https://doi.org/10.1016/j.scienta.2016.01.032

70. Voesenek LACJ, Bailey-Serres J (2015) Flood adaptive traits and processes: an overview. New Phytol 206:5773. https://doi.org/10.1111/nph.13209

71. Wang S, Rao WB, Qian J, Mao CP, Li K (2020) Phosphorus species in bottom sediments of the Three Gorges Reservoir during low and high water level periods. Environ Sci Pollut Res 27:17923-17934. https://doi.org/10.1007/s11356-020-08348-5

72. Waterman R, Sultan SE (2021) Transgenerational effects of parent plant competition on offspring development in contrasting conditions. Ecology 102:e03531. https://doi.org/10.1002/ecy.3531

73. Wei GW, Sun XS, Chen YH, Luo FL, Yu FH (2020) Growth and reproductive responses of Polygonum hydropiper populations to elevational difference associated with flooding. Glob Ecol Conserv 23:e01156. https://doi.org/10.1016/j.gecco.2020.e01156

74. Wei GW, Chen YH, Sun XS, Matsubara S, Luo FL, Yu FH (2021) Elevation-dependent selection for plasticity in leaf and root traits of Polygonum hydropiperin response to flooding. Environ Exp Bot 182:104331. https://doi.org/10.1016/j.envexpbot.2020.104331

75. Xiang R, Wang LJ, Li H, Tian ZB, Zheng BH (2021) Water quality variation in tributaries of the Three Gorges Reservoir from 2000 to 2015. Water Res 195:116993. https://doi.org/10.1016/j.watres.2021.116993

76. Yang CY (2014) Hydrogen peroxide controls transcriptional responses of ERF73/HRE1 and ADH1 via modulation of ethylene signaling during hypoxic stress. Planta 239:877-885.

https://doi.org/10.1007/s00425-013-2020-z

77. Yang F, Liu WW, Wang J, Liao L, Wang Y (2012) Riparian vegetation's responses to the new hydrological regimes from the Three Gorges Project: clues to revegetation in reservoir water-level-fluctuation zone. Acta Ecol Sin 32:89-98. https://doi.org/10.1016/j.chnaes.2012.02.004

78. Yeap WC, Namasivayam P, Ooi TEK, Appleton DR, Kulaveerasingam H, Ho CL (2019) EgRBP42 from oil palm enhances adaptation to stress in Arabidopsis through regulation of nucleocytoplasmic transport of stressresponsive mRNAs. Plant Cell Environ 42:1657-1673. https://doi.org/10.1111/pce.13503

79. Yin X, Sakata K, Nanjo Y, Komatsu S (2014) Analysis of initial changes in the proteins of soybean root tip under flooding stress using gel-free and gel-based proteomic techniques. J Proteom 106:1-16. https://doi.org/10.1016/j.jprot.2014.04.004 
80. Zamorano D, Franck N, Pastenes C, Wallberg B, Garrido M, Silva H (2021) Improved physiological performance in grapevine (Vitis vinifera L.) cv. Cabernet Sauvignon facing recurrent drought stress. Aust $J$ Grape Wine Res 27:258-268. https://doi.org/10.1111/ajgw.12482

81. Zhang Q, Visser EJW, de Kroon H, Huber H (2015) Life cycle stage and water depth affect flooding-induced adventitious root formation in the terrestrial species Solanum dulcamara. Ann Bot-London 116:279-290. https://doi.org/10.1093/aob/mcv095

82. Zhang ZY, Wan CY, Zheng ZW, Hu L, Feng K, Chang JB, Xie P (2013) Plant community characteristics and their responses to environmental factors in the water level fluctuation zone of the Three Gorges Reservoir in China. Environ Sci Pollut Res 20:7080-7091. https://doi.org/10.1007/s11356-013-1702-1

83. Zhou WG, Chen F, Meng YJ, Chandrasekaran U, Luo XF, Yang WY, Shu K (2020) Plant waterlogging/flooding stress responses: from seed germination to maturation. Plant Physiol Bioch 148:228-236.

https://doi.org/10.1016/j.plaphy.2020.01.020

\section{Figures}




\section{Early treatments Subsequent treatments}

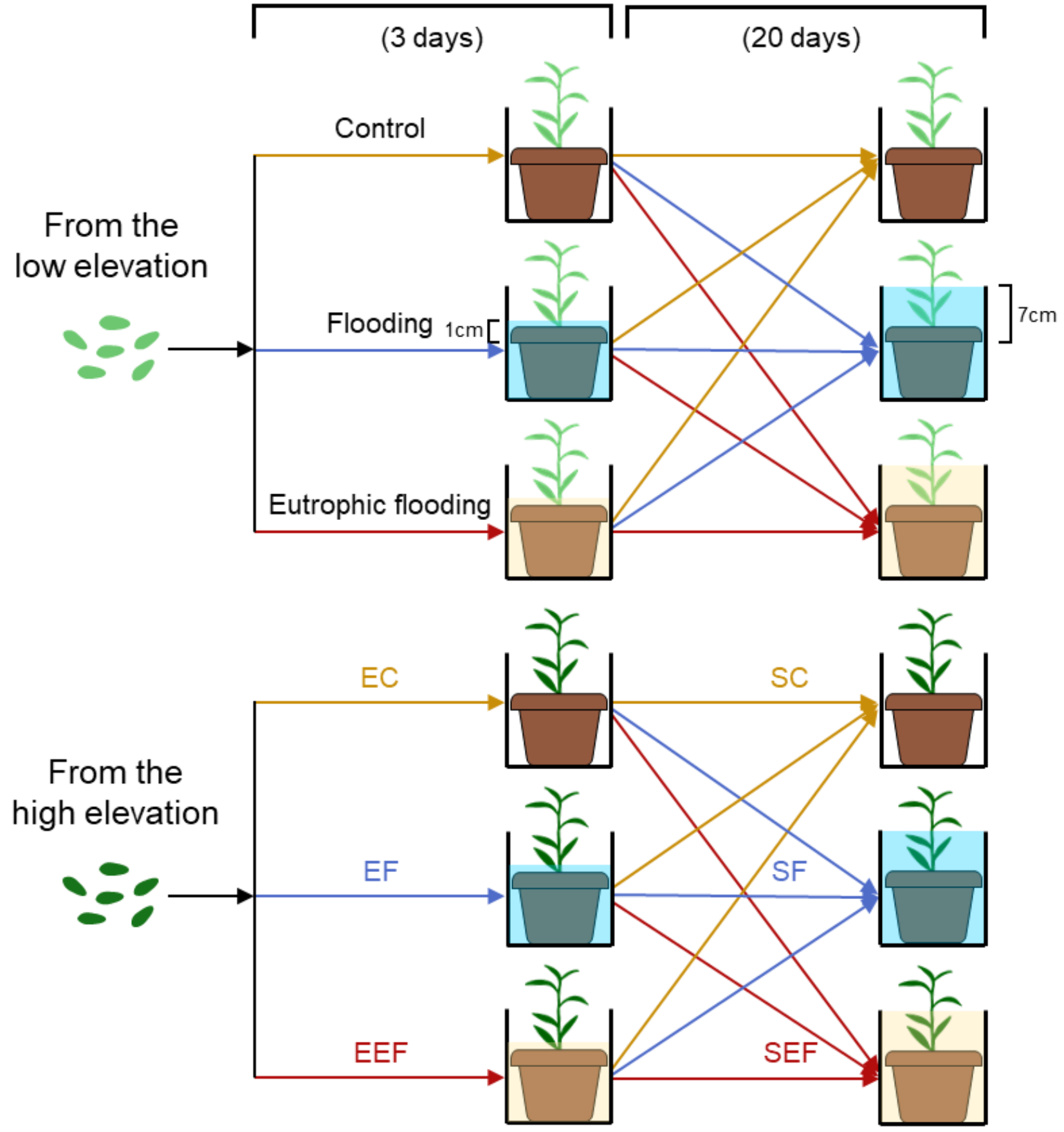

Figure 1

Schematic representation of the experimental design. Seeds of Polygonum hydropiper were collected from three populations each at low and high elevations in the Three Gorges Reservoir (TGR) region. The early treatments included early control (no flooding, EC), early flooding (with a floodwater depth of $1 \mathrm{~cm}$ above the soil surface, EF), and eutrophic flooding treatments (with an eutrophic floodwater depth of $1 \mathrm{~cm}$ above the soil surface, EEF). After the early treatments, plants were subjected to three subsequent flooding treatments: control (no flooding, SC), flooding (where the floodwater depth was $7 \mathrm{~cm}$ above the soil surface, SF), and eutrophic flooding (where the eutrophic floodwater depth was $7 \mathrm{~cm}$ above the soil surface, SEF). The $\mathrm{N}$ and $\mathrm{P}$ concentrations of eutrophic water were 2 and $0.15 \mathrm{mg} \mathrm{L}^{-1}$, respectively, which were set in reference to the eutrophication level of water in the TGR. 


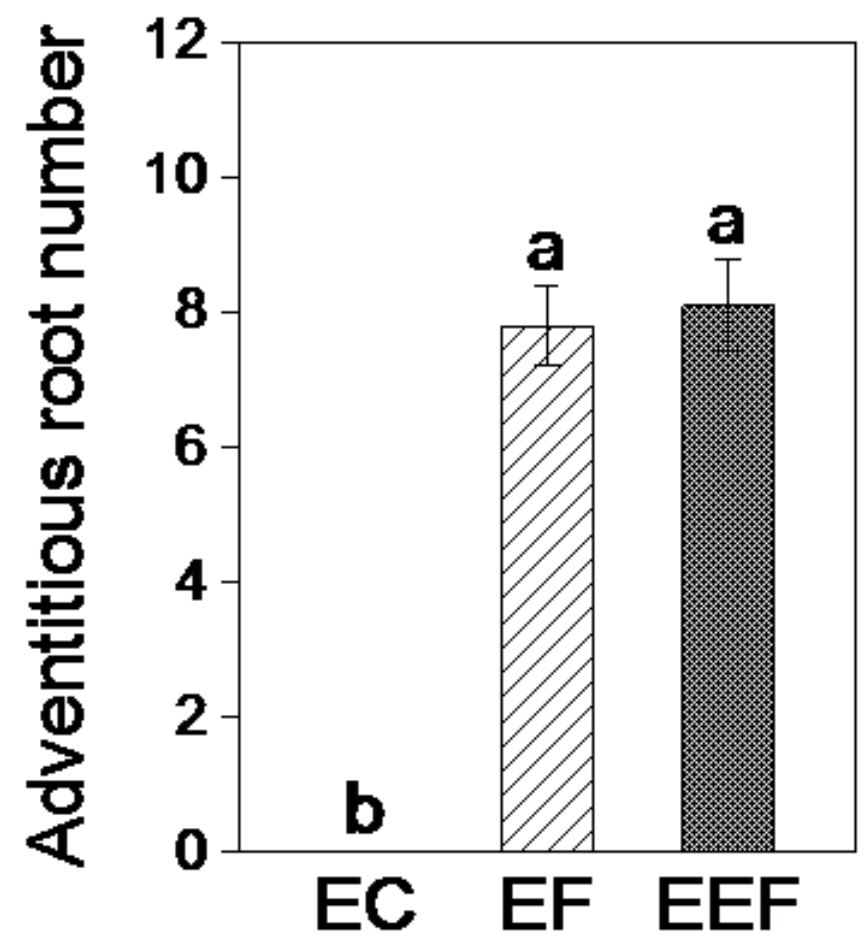

Figure 2

Adventitious root number of $P$. hydropiper subjected to early control (EC), early flooding (EF), and early eutrophic flooding (EEF). Different lowercase letters represent significant differences among the three early treatments.
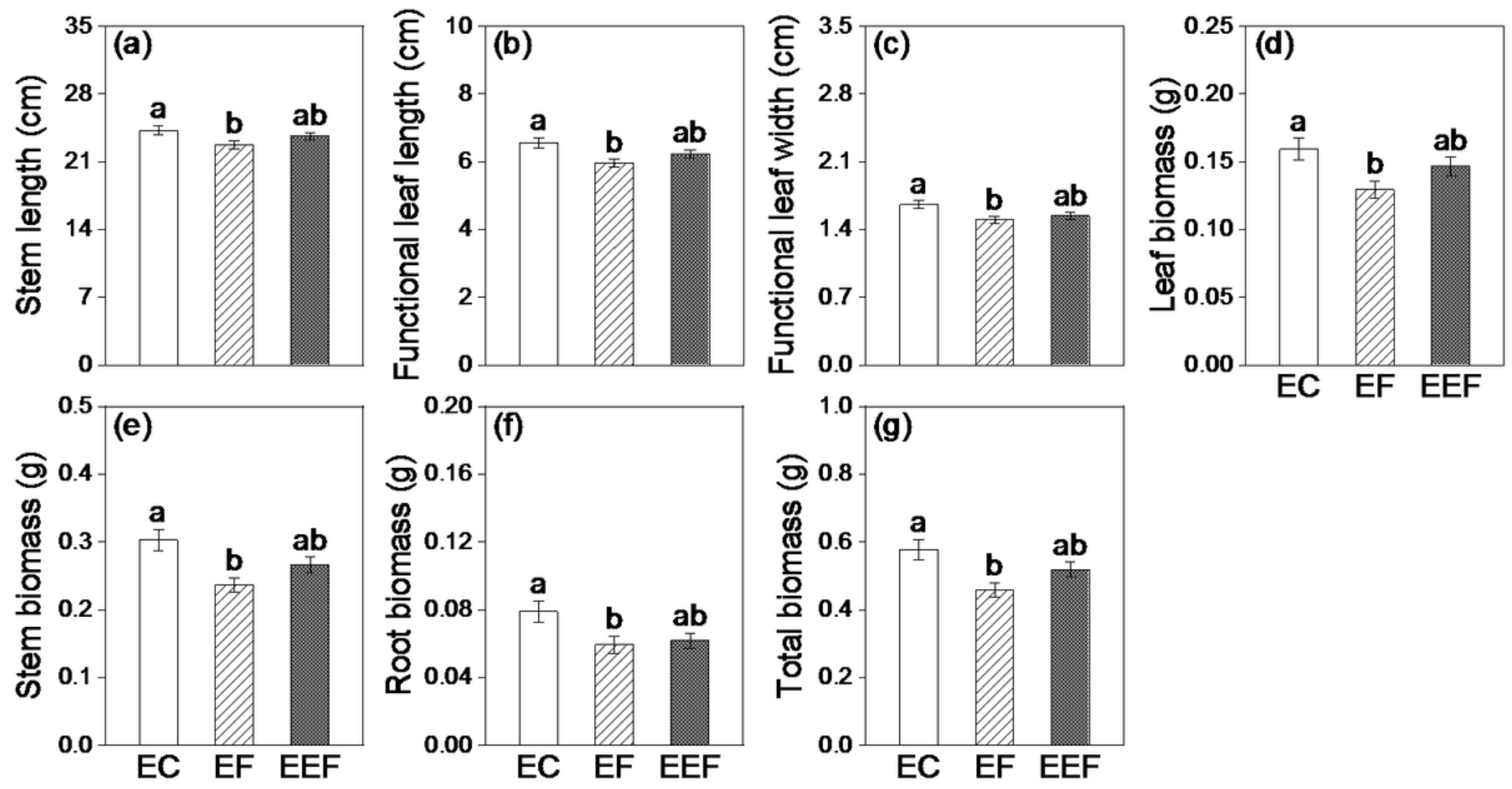

Figure 3 
Growth variables of $P$. hydropiper after treatments of EC, EF, and EEF on day 20. Abbreviations of different treatments are described in Fig. 2. Different lowercase letters represent significant differences among early treatments.
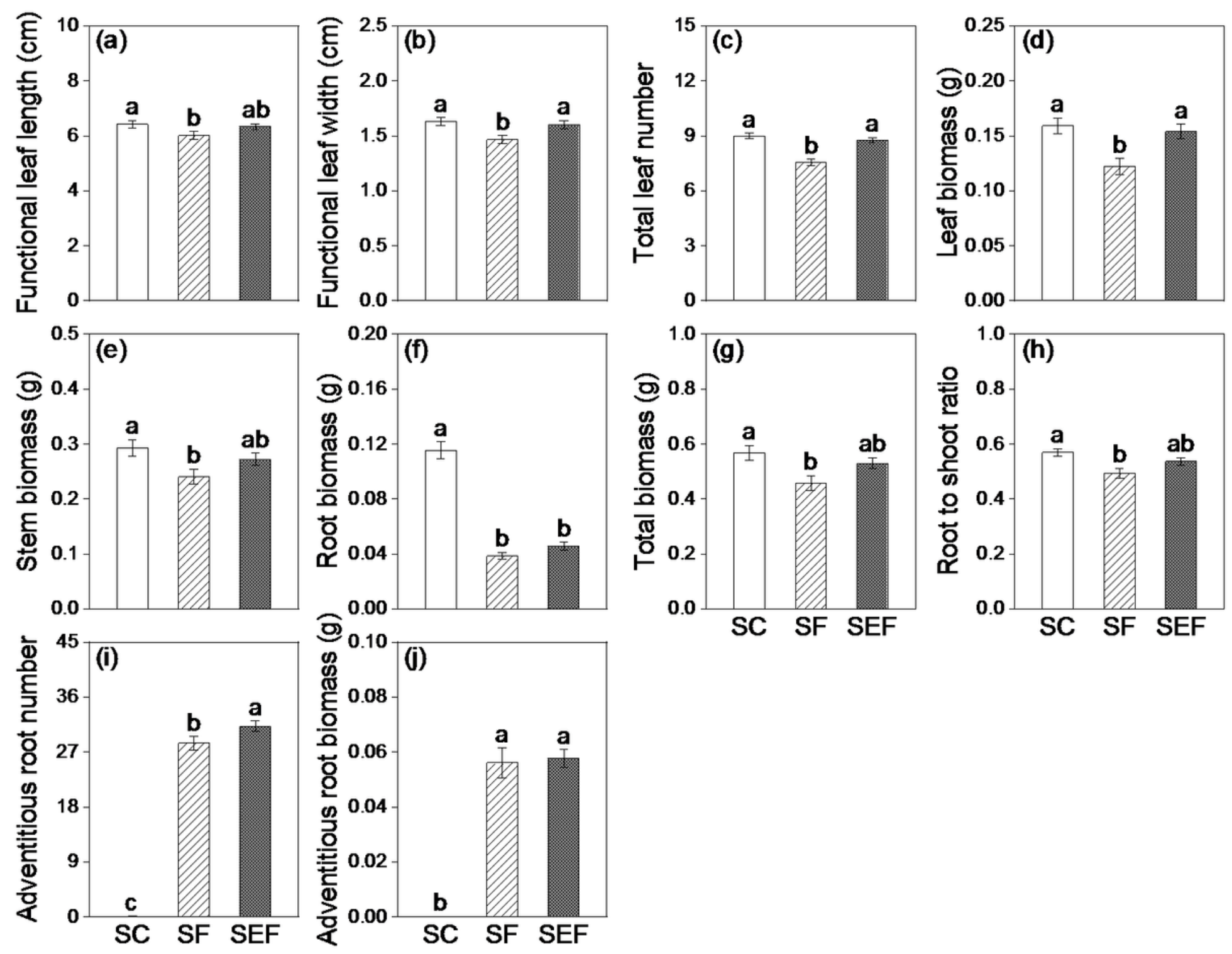

Figure 4

Growth variables of $P$. hydropiper after the subsequent treatments of control (SC), flooding (SF), and eutrophic flooding (SEF) on day 20. Different lowercase letters represent significant differences among subsequent treatments. 

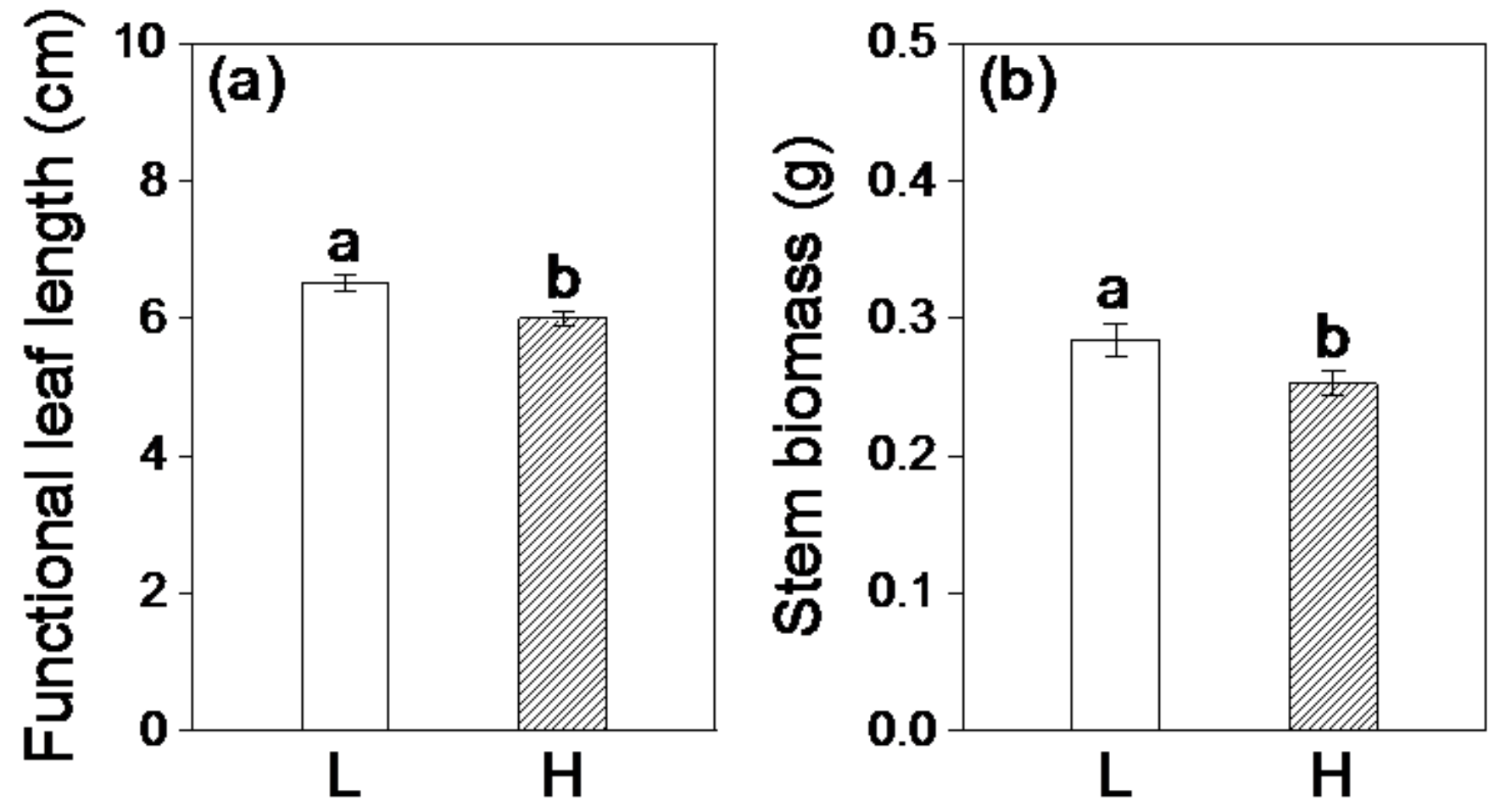

Figure 5

Growth variables of $P$. hydropiperfrom low $(\mathrm{L})$ and high $(\mathrm{H})$ elevations on day 20. Different lowercase letters represent significant differences between two elevations.

\section{Supplementary Files}

This is a list of supplementary files associated with this preprint. Click to download.

- ChenSupplementaryMaterial.docx 